\title{
KEPERCAYAAN DALAM PERSPEKTIF KOMUNIKASI UMUM DAN PERSPEKTIF KOMUNIKASI ISLAM
}

\author{
Anwar Yacob \\ Kasubbag Administrasi Akademik pada Biro AUAK \\ Institut Agama Islam Negeri Langsa
}

\begin{abstract}
Abstrak
Kepercayaan adalah kemauan seseorang untuk bertumpu pada orang lain dimana kita memiliki keyakinan padanya. Kepercayaan merupakan kondisi mental yang didasarkan oleh situasi seseorang dan konteks sosialnya. Ketika seseorang mengambil suatu keputusan, ia akan lebih memilih keputusan berdasarkan pilihan dari orang- orang yang lebih dapat ia percaya dari pada yang kurang dipercayai . Dari sudut pandang komunikasi, hal ini menyatakan bahwa perkembangan kepercayaan seharusnya menjadi komponen fundamental dari strategi berkomunikasi yang efektif dan efisien. Berbicara dengan data dan informasi yang akurat adalah salah satu dari prinsip komunikasi dalam islam yang mengesankan bahwa pembawa pesan merupakan orang yang memiliki pribadi yang berkualitas, selain menambah kredibilitas, informasi yang akurat menghin dari seorang yang berbicara atau menyampaikan pesan berujung pada penyesalah
\end{abstract}

Kata Kunci : Kepercayaan, Komunikasi umum , Komunikasi Islam

\section{A. Kepercayaan Dalam Tinjauan Filsafat.}

Kepercayaan adalah suatu keadaan psikologis pada saat seseorang menganggap suatu premis, (Schwitzgebel, 2006) Kepercayaan adalah kemauan seseorang untuk bertumpu pada orang lain dimana kita memiliki keyakinan padanya. Kepercayaan merupakan kondisi mental yang didasarkan oleh situasi seseorang dan konteks sosialnya. Ketika seseorang mengambil suatu keputusan, ia akan lebih memilih keputusan berdasarkan pilihan dari orangorang yang lebih dapat ia percaya dari pada yang kurang dipercayai .

Menurut Rousseau et al (1998), kepercayaan adalah wilayah psikologis yang merupakan perhatian untuk menerima apa adanya berdasarkan harapan terhadap perilaku yang baik dari orang lain. Kepercayaan (trust) merupakan tindakan kesediaan (willingness) 
individu untuk menggantungkan dirinya pada pihak lain yang terlibat dalam pertukaranmakna/ informasi karena individu mempunyai keyakinan (confidence) kepada pihak lain. Ketika satu pihak mempunyai keyakinan (confidence) bahwa pihak lain yang terlibat dalam pertukaran mempunyai reliabilitas dan integritas, maka dapat dikatakan ada trust. (kutipan dari jurnal Moorman Rohit Deshpande dan Gerald Zaltman. yang berjudul "Factors Affecting Trust in Market Research Relationships", Journal of Marketing, Vol. 57, January, pp. 81-101,1993)

Rofiq mendefinisikan kepercayaan (trust) adalah kepercayaan pihak tertentu terhadap yang lain dalam melakukan hubungan transaksi berdasarkan suatu keyakinan bahwa orang yang dipercayainya tersebut memiliki segala kewajibannya secara baik sesuai yang diharapkan. (Ainur Rofiq,2007) Kepercayaan konsumen menurut Mowen adalah semua pengetahuan yang dimiliki oleh konsumen dan semua kesimpulan yang dibuat konsumen tentang objek, atribut, dan manfaatnya. (John C Mowen,2002:312)

Kepercayaan muncul ketika satu pihak mempunyai keyakinan (confidence) bahwa pihak lain yang terlibat dalam pertukaran mempunyai reliabilitas dan integritas, maka dapat dikatakan ada trust.

Kepercayaan, sikap, dan perilaku terbentuk dengan dua cara berbeda. Pada formulasi langsung, kepercayaan, sikap, dan perilaku diciptakan tanpa terjadi keadaan lain sebelumnya. Jadi, seperti ditunjukkan oleh perspektif pengaruh perilaku, perilaku dapat terjadi tanpa pembentukan sikap atau kepercayaan awal konsumen yang kuat tentang objek di mana perilaku di arahkan.

Demikian juga, seperti dinyatakan oleh perspektif eksperiensial sikap (misalnya, perasaan) dapat tercipta tanpa pengembangan kepercayaan spesifik awal Komunikan terhadap komunikator.

Mowen menambahkan bahwa setelah kepercayaan, sikap, atau perilaku terbentuk secara langsung terdapat tendensi atas tiga keadaan yang dapat menciptakan sebuah hierarki. Dengan cara ini, pertama-tama konsumen membentuk kepercayaan terhadap sebuah produk dan kemudian membentuk kepercayan serta sikap terhadap produk tersebut. (John C Mowen,2002:322)

Dari sudut pandang komunikasi, hal ini menyatakan bahwa perkembangan kepercayaan seharusnya menjadi komponen fundamental dari strategi berkomunikasi yang efektif dan efisien . 
Seorang komunikator harus mampu merasakan bahwa dia dapat mengandalkan dirinyabahwadirinyadapat dipercaya. Akan tetapi, untuk membangun kepercayaan membutuhkan waktu lama dan hanya dapat berkembang setelah pemakaian yang berulangkali terhadap seseorang.Lebih penting, kepercayaan berkembang setelah seorang individu mengambil resiko dalam berhubungan dengan apa yang telah digunakannya

Sementara keyakinan adalah suatu sikap yang ditunjukkan oleh manusia saat ia merasa cukup tahu dan menyimpulkan bahwa dirinya telah mencapai kebenaran. (Dani Vardiansyah, 2008:2) Karena keyakinan merupakan suatu sikap, maka keyakinan seseorang tidak selalu benar atau, keyakinan semata bukanlah jaminan kebenaran. Contoh: Pada suatu masa, manusia pernah meyakini bahwa bumi merupakan pusat tata surya, belakangan disadari bahwa keyakinan itu keliru.

\section{Persepsi Titik Utama Berkomunikasi}

Kepercayaan dalam komunikasi sangat erat hubungan dengan persepsi, persepsi sering dimaknakan dengan pendapat, sikap, penilaian, perasaan dan lain-lain. Yang pasti tindakan persepsi, penilaian, perasaan, bahkan sikap selalu berhadapan dengan suatu objek atau peristiwa tertentu.

Berhubung persepsi melibatkan aktivitas manusia terhadap objek tertentu, maka persepsi selalu menggambarkan pengalaman manusia tentang objek, peristiwa, atau hubungan-hubungan yang diperoleh dengan menyimpulkan informasi dan menafsirkan pesan tentang objek terebut.

Persepsi manusia sebenarnya terbagi dua yaitu persepsi terhadap objek (lingkungan fisik) dan persepsi terhadap manusia (lingkungan sosial). Lebih sulit dan kompleks, karena manusia bersifat dinamis.

Persepsi terhadap lingkungan fisik sangat berbeda dengan persepsi terhadap lingkungan sosial, perbedaan tersebut mencakup hal-hal berikut:

a. Persepsi terhadap objek melalui lambang-lambang fisik, sedangkan persepsi terhadap orang melalui lambang-lambang verbal maupun non verbal. Orang lebih aktif daripada kebanyakan objek dan lebih sulit diramalkan.

b. Persepsi terhadap objek menanggapi sifat-sifat luar, sedangkan persepsi terhadap orang menanggapi sifat-sifat luar dan dalam (perasaan, motif, harapan, dan sebagainya).

c. Objek tidak bereaksi, sedangkan manusia bereaksi. Dengan kata lain objek bersifat statis, sedangkan manusia bersifat dinamis. Oleh karena itu persepsi terhadap manusia 
dapat berubah dari waktu ke waktu, lebih cepat daripada persepsi terhadap objek. (Alex Sobur, 3013:468)

Persepsi juga ditentukan oleh faktor fungsional dan struktural. Beberapa faktor fungsional atau faktor yang bersifat personal antara lain kebutuhan individu, pengalaman, usia, masa lalu, kepribadian, jenis kelamin, dan lain-lain yang bersifat subjektif. Faktor struktural atau faktor dari luar individu antara lain lingkungan keluarga, hukum-hukum yang berlaku, dan nilai-nilai dalam masyarakat.

Jadi, faktor-faktor yang mempengaruhi perepsi terdiri dari faktor personal dan struktural. Faktor-faktor personal antara lain pengalaman, proses belajar, kebutuhan, motif dan pengetahuan terhadap objek psikologis. Faktor- faktor struktural meliputi lingkungan keadaan sosial, hukum yang berlaku, nilai- nilai dalam masyarakat. (Jalaluddin Rakhmat, 2008:49)

Salah satu pandangan yang dianut secara luas menyatakan bahwa psikologi sebagai telaah ilmiah berhubungan dengan unsur dan proses yang merupakan perantara rangsangan di luar organisme dengan tanggapan fisik organisme yang dapat diamati terhadap rangsangan. Menurut rumus ini, yang dikenal dengan teori rangsangan-tanggapan (stimulus-responden/S$\mathrm{R}$ ), persepsi merupakan bagian dari keseluruhan proses yang mengahasilkan tanggapan setelah rangsangan diterapkan kepada manusia. Subproses psikologis lainnya adalah pengenalan, penalaran, perasaan, tanggapan.

Seperti dinyatakan dalam bagan berikut, persepsi dan kognisi diperlukan dalam semua kegiatan psikologis. Bahkan diperlukan bagi orang yang paling sedikit terpengaruh atau sadar akan adanya rangsangan menerima dan dengan suatu cara menahan dampak dari rangsangan.Variabel psikologis di antaran rangsangan dan tangapan. (Alex Sobur, 3013:467)

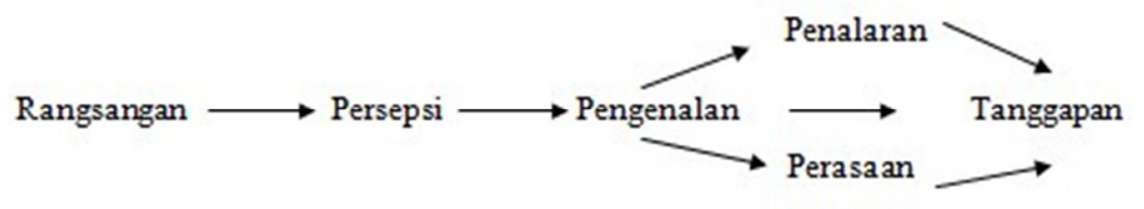

Rasa dan nalar merupakan bagian yang perlu dari setiap situasi rangsanga- tanggapan, sekalipun kebanyakan tanggapan indivdu yang sadar dan bebas terhadap satu rangsangan atau terhadap satu bidang rangsangan sampai tingkat tertentu dianggap dipengaruhi oleh akal atau emosi, atau kedua-duanya. 
Secara singkat persepsi dapat didefenisikan sebagai cara manusia menangkap rangsangan. Kognisi adalah cara manusia memberi arti terhadap rangsangan. Penalaranadalah proses sewaktu rangsangan dihubungkan dengan rangsangan lainnya pada tingkat pembentukan psikologi. Perasaan adalah konotasi emosional yang dihasilkan oleh rangsangan baik sendiri atau bersama-sama dengan rangsangan lain pada tingkat kognitif atau konseptual.

Dari segi psikologi dikatakan bahwa tingkah laku seseorang merupakan fungsi dari cara diamemandang. Oleh sebab itu untuk mengubah tingkah laku seseorang harus dimulai dengan mengubah persepsinya. Dalam persepsi terdapat tiga komponen utama berikut. (Alex Sobur, 3013:466)

a. Seleksi, adalah proses penyaringan oleh indra terhadap rangsangan dari luar, intensitas dan jenisnya dapat banyak atau sedikit.

b. Interpretasi, yaitu proses mengorganisikan informasi sehingga mempunyai arti bagi seseorang. Interpretasi dipengaruhi oleh beberapa faktor, seperti pengalaman masa lalu, sistem nilai yang dianut, motivasi kepribadian, dan kecerdasan. Interpretasi juga bergantung pada kemampuan seseorang untuk mengadakan pengkategorian informasi yang diterimanya, yaitu proses mereduksi informasi yang kompleks menjadi sederhana.

c. Interpretasi dan persepsi kemudian diterjemahkan dalam bentuk tingkah laku sebagai reaksi.

\section{Kredibilitas}

Kepercayaan adalah kesan komunikan tentang watak komunikator. Komunikan biasanya akan menilai apakah komunikator itu mempunyai sifat jujur, tulus, sopan dan etis. (Jalaluddin Rakhmat, 2008:260)Seseorang disebut komunikator jika ia menyampaikan sesuatu kepada rang lain. Komunikator adalah seseorang atau sekelompok orang yang menyampaikan pikirannya atau perasannya kepada orang lain.

Seorang komunikator harus tetap memperhatikan sikapnya di depan komunikannya. Hal ini bertujuan agar pesan yang disampaikan dapat diterima dengan baik oleh komunikan. Untuk menciptakan komunikasi yang baik dan tepat maka komunikator harus memperhatikan pesan yang disampaikan. Pesan itu harus disampaikan dengan sopan, harus di perhitungkan kadar kepribadiannya, kebiasaan, pola hidup nilai-nilai komunikan. Nilai etis etis sangat menentukan sekali bagaimana orang bisa bersikap terbuka. 
Komunikator harus memperhatikan perilaku ketika menyampaikan pesan. Komunikan akan melihat terlebih dahulu siapa yang menyampaikan pesan kepada dirinya. Jika komunikan telah memandang negatif kepada komunikatornya itu maka komunikan tidak akan mempercayainya.

Kredibilitas sangat penting untuk menentukan berhasil tidaknya suatu pesan yang disampaikan, penilaian tersebut tergantung kepada persepsi komunikan terhadap komunikatornya. Namun pihak komunikatorpun tentu akan berusaha agar dirinya dinilai baik sehingga komunikan akan dapat mempercayainya.

Komunikator harus terus melatih diri untuk berbicara kepada komunikan sehingga jika sering melakukannya akan timbul kepercayaan diri pada diri komunikator . Untuk meningkatkan percaya diri, menumbuhkan konsep diri yang sehat menjadi perlu. Percaya diri adalah faktor yang menentukan ketakutan orang untuk berkomunikasi. (Jalaluddin Rakhmat, 2008:109)

Jika komunikator sudah tidak memiliki kepercayaan diri untuk berbicara di depan komunikan maka nilai kredibilitas dia rendah. Apa yang disampaikan tidak akan di dengar oleh komunikan. Komunikator akan memperlihatkan ketakutannya dalam berkomunikasi. Bicaranya menjadi tidak jelas dan tidak bersemangat karena ketakutannya itu.

Untuk itu perlu dibiasakan tampil di depan khalayak agar terbiasa berbicara kepada komunikannya. Jika sudah terbiasa maka pesan yang disampaikan akan disampaikan dengan situasi yang menyenangkan bagi komunikan. Dengan seringnya tampil maka pengalaman dari komunikator akan bertambah dan belajar dari kesalahan-kesalahan sebelumnya.

Pengalaman mempengaruhi kecermatan persepsi. Pengalaman tidak hanya datang lewat proses belajar normal tetapi pengalaman kita bertambah juga melalui rangkaian peristiwa yang pernah dihadapi.

Untuk dapat dipercaya oleh komunikan, seorang komunikator harus memiliki kesamaan dengan komunikannya. Kesamaan antara komunikator dengan komunikannya ini untuk memudahkan terjadinya perubahan pendapat, hal ini di maksudkan sebagai strategi dari komunikator untuk mempengaruhi orang lain. Komunikator yang ingin mempengaruhi orang lain sebaiknya memulai dengan menegaskan kesamaan antara dirinya dengan komunikan.

Menurut Wilbur Schramm yang dikutip Onong Uchjana Effendy (OnongUchjana Effendi, 1993:30-31) menyebutkan bahwa field of experience atau bidang pengalaman merupakan faktor yang amat penting untuk terjadinya komunikasi. Apabila bidang pengalaman komunikator sama dengan bidang pengalaman komunikan, komunikasi akan 
berlansung lancar. Sebaliknya, jikalau pengalaman komunikan tidak sama dengan pengalaman komunikator, akan timbul kesukaran untuk mengerti satu sama lain; dengan lain perkataan situasi menjadi tidak komunikatif; atau dengan rumusan lain terjadi misscommunicatio.

Komunikator yang memiliki kesamaan dengan komunikan cenderung berkomunikasi dengan efektif karena ada ketertarikan komunikan kepada komunikatornya disebabkan adanya kesamaan itu. Jika komunikator dan komunikan memiliki kesamaan persepsi mengenai sikap dan kepercayaan terhadap suatu persoalan maka akan lebih mudah untuk memecahkannya karena mempunyai keinginan dan harapan yang sama pula dalam memandang persoalan itu.

Komunikator yang memiliki kredibilitas yang tinggi selalu memperhatikan pesan yang akan disampaikannya dan selalu berubah dalam menyampaikan pesannya karena senantiasa di sesuaikan dengan sifat dan kedudukan komunikannya. Apabila komunikasi yang dijalankan komunikator telah berjalan dengan efektif, maka pesan yang disampaikan komunikator akan menimbulkan perubahan sikap dan perilaku dalam diri komunikan.

Berdasarkan uraian diatas maka komponen kredibilitas yang paling penting adalah keahlian dan kepercayaan. Seorang komunikator harus bisa memahami apa yang menjadi kebutuhan dan keinginan komunikan. Seorang komunikator yang sukses dalam menyampaikan pesannya yaitu apabila komunikator tersebut mampu menyampaikan pesan sesuai dengan kebutuhan dan keinginan komunikannya. Dengan demikian komunikasi yang dilakukannya berjalan dengan efektif.

\section{B. Kepercayaan DalamPerspektif Komunikasi Islam.}

Berbicara dengan data dan informasi yang akurat adalah salah satu dari prinsip komunikasi dalam islam yang mengesankan bahwa pembawa pesan merupakan orang yang memiliki pribadi yang berkualitas, (Harjani Hefni, 2015:254) selain menambah kredibilitas, informasi yang akurat menghin dari seorang yang berbicara atau menyampaikan pesan berujung pada penyesalah, seperti firman Allah:

"Hai orang-orang yang beriman, jika datang kepadamu orang Fasik membawa suatu berita, Maka periksalah dengan teliti agar kamu tidak menimpakan suatu musibah kepada suatu kaum tanpa mengetahui keadaannya yang menyebabkan kamu menyesal atas perbuatanmu itu” (Al-Hujaratayat 6)

Kata kunci pada ayat ini adalah kata "Telitilah Kebenarannya!". Dengan tegas AlQur'an mengajarkan kepada kita untuk mengecek informasi yang kita dengar. Pada ayat-ayat 
selanjutnya, Allah berbicara tentang persatuan. Sehingga kita dapat mengambil pelajaran bahwa salah satu penyebab rusaknya persatuan adalah karena mudah menerima berita tanpa mengecek kebenarannya.

Apalagi seorang yang membawa informasi itu adalah orang fasiq,audiena harus lebih berhati-hati ketika mendengar informasi dari mereka. Allah SWT mengajarkan kepada kita untuk mengecek semua informasi dari siapapun.

Retaknya bangunan rumah tangga misalnya. Banyak kasus yang diawali dengan kabar angin yang langsung diterima dan diceritakan. Padahal semua itu hanyalah gerakan lisan tanpa ada bukti. Maraknya gosip menjadi salah satu penyebab hancurnya rumah tangga seseorang. Gosip itu seakan ringan diucapkan dan disebar luaskan, namun di mata Allah menjadi perkara yang besar.

Dalam sebuah riwayat disebutkan Imam Ja'far As-Shodiq ketika ada seorang sahabat yang melaporkan temannya yang berbuatburuk, beliau sering mengatakan, "Dustakan matamu, dustakan pendengaranmu!” Jangan berburuk sangka kepada orang lain. Karena seorang yang menyampaikan berita sementara dia belum tahu kebenarannya, maka dia adalah termasuk dari salah satu dari dua pembohong.

Semakin strategis tema yang dibicarakan seperti tentang kenabian, pesan-pesan yang disampaikan, maka data yang disampaikan harus benar-benar valid dan diterima secara selektif.

Prinsip selektivitas dan validitas dalam komunikasi islam bukanlah bertujuan untuk memberikan kepuasan di duniawi (aktifitas hubungan di alam dunia saja) namun komunikasi yang terjadi diantara manusia akan dipertanggungjawabkan kelak di akhirat, sehingga komunikasi yang terbangung memiliki hubungan ilahiyah. (Harjani Hefni, 2015:255)

\section{Penutup}

Kepercayaan merupakan kunci utama dari keberhasilan komunikasi, pertukaran pesan yang dilakukan oleh komunikator dan komunikan akan berjalan dengan baik ketika terjadi saling percaya dan kesamaan persepsi diantara keduanya.

Prinsip selektivitas dan validitas dalam komunikasi islam bukanlah bertujuan untuk memberikan kepuasan di duniawi (aktifitas hubungan di alam dunia saja) namun komunikasi yang terjadi diantara manusia akan dipertanggungjawabkan kelak di akhirat, sehingga komunikasi yang terbangung memiliki hubungan ilahiyah 


\section{DAFTAR PUSTAKA}

Ardianto,Elvinaro, dkk, Komunikasi Massa. Bandung :Simbiosa Rekatama Media, 2007.

Ainur Rofiq, Pengaruh Dimensi Kepercayaan (trust) Terhadap Partisipasi. Pelanggan Ecommerce ,tesis Universitas Brawi. Jaya malang, Tidak diterbitkan,2007

Alex sobur, Psikologi Umum Dalam Lintasan sejarah, Bandung Pustaka setia, 2013

Effendi ,onong Uchjana, Ilmu, Teori dan Filsafat Komunikasi, Bandung :Pt Citra Aditya bakti, 1993

Fiske, John, Pengantar Ilmu Komunikasi, Jakarta: Raja grafindo Persada,2012.

Harjani Hefni, Komunikasi Islam, Jakarta: PT Fajar Interpratama Mandiri, 2015

Liliweri, Alo, Komunikasi Serba Ada Serba Makna, Jakarta: Kencana, 2001

Mulyana, Dedy. Ilmu Komunikasi, Bandung: PT Remaja Rosdakarya, 2000

Moorman Rohit Deshpande, dan Gerald Zaltman, "Factors Affecting Trust in Market Research Relationships”, Journal of Marketing, Vol. 57, January, pp. 81-101,1993.

Syam,Nina W, Model-model komunikasi, perpektif Pohon Komunikasi, Bandung :Simbiosa Rekatama Media, 2013

Vivian, John. TeoriKomunikasimassa,Cet 2, Jakarta: Prenadamedia Group, 2015.

Vardiansyah, Dani. Filsafat Ilmu Komunikasi: Suatu Pengantar, Indeks, Jakarta 2008 